\title{
SAMOPROCJENA IZGOVORA NEIZVORNIH GOVORNIKA HRVATSKOG JEZIKA
}

\author{
Ivančica Banković-Mandić \\ Filozofski fakultet Sveučilišta u Zagrebu
}

Sociofonetska istraživanja pokazuju da su odstupanja u izgovoru u hrvatskom javnom govoru uglavnom lošije ocijenjena te da se uz odstupanja vežu negativne osobine ličnosti. U privatnoj komunikaciji veća je tolerancija na odstupanja. No, regionalni govor ne procjenjuje se u svim jezicima negativno.

U radu se želi pokazati mogu li se neizvorni govornici hrvatskog jezika prema samoprocjeni izgovora grupirati prema jezicima. Pretpostavka je da će govornici srodnih jezika s hrvatskim navesti manje varijabli odstupanja od govornika nesrodnih jezika.

Za istraživanje su prikupljena 73 upitnika samoprocjene izgovora hrvatskog na različitim jezičnim razinama prema ZEROJ-u. Ispitivale su se sljedeće varijable: intonacije, vokali, konsonanti i naglasci. Upitnik je bio otvorenog tipa pa su ispitanici mogli navesti još neke varijable koje nisu bile ponuđene. Ispitanici su na skali od 1 do 5 ocijenili svoj izgovor.

Rezultati istraživanja mogu biti smjernica u radu lektoru hrvatskog jezika kako bi govornik inojezičnog hrvatskog imao prihvatljiv izgovor sukladno razini poznavanja hrvatskog jezika.

Ključne riječi: samoprocjena, izgovor, inojezični hrvatski

\section{UVODNO O TOLERANCIJI IZGOVORA NEIZVORNIH GOVORNIKA}

$\mathrm{U}$ posljednjih je tridesetak godina objavljeno nekoliko radova o sociofonetskim istraživanjima hrvatskog kao materinskog i hrvatskog kao drugog jezika. Istraživanja procjene izgovora pokazuju da se $u$ javnom prostoru izgovor procjenjuje strože nego u privatnoj komunikaciji $\mathrm{i}$ to $\mathrm{i}$ za izvorne i za neizvorne govornike hrvatskog jezika. Izgovor neizvornih govornika hrvatskog jezika posve je prihvatljiv u privatnoj komunikaciji (Šafarić i dr., 2006), za akademska zvanja i uslužne djelatnosti izgovor se strože procjenjuje, ali su procjenitelji vrlo tolerantni u procjeni izgovora stranih studenata (Banković-Mandić, 2012). Neizvorni govornici hrvatskog jezika strogi su u ocjeni vlastita izgovora (Banković-Mandić i Čilaš Mikulić, 2016; Banković-Mandić, 2016; Banković-Mandić, 2018). U istraživanju svjesnosti izgovora vokala neizvornih govornika hrvatskog jezika (BankovićMandić, 2016:377) 40 \% neizvornih govornika hrvatskog jezika misli da treba korigirati svoje vokale, a perceptivna analiza stručnih procjenitelja donosi

\footnotetext{
*ibmandic@gmail.com
} 
podatke da korekciju treba trećina ispitanika. U istraživanju svjesnosti izgovora hrvatskih naglasaka od 44 ispitanika u hrvatskome kao J2, samo njih četvero misli da je njihov naglasni sustav dobar iako u svojem naglasnom sustavu hrvatskog kao J2 prema objektivnoj perceptivnoj analizi nemaju brojna odstupanja (Banković-Mandić i Čilaš Mikulić, 2016). Kada izgovor neizvornih govornika procjenjuju izvorni govornici hrvatskog jezika koji nisu stručni procjenitelji, ocjene su niže od ocjena izvornih govornika kao stručnih procjenitelja (Banković-Mandić, 2012, 2018). Na isti način izvorni govornici slovenskog jezika procjenjuju neizvorne govornike slovenskog jezika (Požgaj Hadži, 2013). Pod stručnim se procjeniteljima hrvatskog jezika smatraju oni procjenitelji koji se bave poučavanjem i istraživanjem hrvatskog jezika kao drugog i stranog.

N. Jakovčević (1988) zaključila je da ispitanici prednost daju hrvatskomu standardnomu govoru u javnomu području, a u privatnomu su tolerantni prema svim varijetetima. V. Mildner $(1999,2009) \mathrm{u}$ istraživanju tolerancije hrvatskih varijeteta zaključuje da su ispitanici najkritičniji prema upotrebi varijeteta hrvatskoga jezika u elektroničkim medijima, govoru nastavnika i liječnika.

Uz odstupanja se vezuju i negativne osobine ličnosti (Varošanec-Škarić i Kišiček, 2009: 116) - govornici čiji se govor procjenjuje prihvatljivim u javnoj uporabi ujedno je procijenjen kao neregionalni, govor više klase, višega stupnja naobrazbe, intelektualnoga zanimanja i prijateljski je prihvaćeniji. G. Kišiček $(2012: 159,160)$ donosi rezultate istraživanja o umjerenoj korelaciji regionalnosti i procjene društvenog statusa, naobrazbe te inteligencije, tj. osobe čiji je govor regionalan procjenitelji smatraju pripadnicima nižeg društvenog statusa, nižeg stupnja naobrazbe, neintelektualnog zanimanja, pa čak i manje inteligentnima od osoba čiji je govor procijenjen neregionalnim. Sociofonetska istraživanja hrvatskog standardnog naglašavanja provode Škarić (1999, 2001), Škarić i Lazić (2002), Škarić i Varošanec-Škarić (2003), istražujući vrijednosne sudove o hrvatskim naglascima, ispitujući kakvi su stavovi slušača prema "pogrešnim“ naglascima te koji se naglasci percipiraju više kao hrvatski, a rezultati navode prihvatljivost i prednost $\mathrm{tz}$. općeprihvaćenog izgovora. J. Granić (1994) navodi da danas supstandard konkurira standardu i želi preuzeti dominaciju standarda u govoru. O standardu i jezičnim varijetetima hrvatskog jezika iz perspektive funkcionalne uporabe piše Mićanović (2008) te potvrđuje elastičnost kao odrednicu standarda.

Regionalno obilježen govor ne procjenjuje se u svim sredinama i u svim razdobljima kao pokazatelj nižega društvenoga statusa. Kalogjera (2003) navodi da u Velikoj Britaniji prihvaćeni izgovor (engl. Received Pronunciation, kraticom RP) nije više statusni simbol, većizgovor mlađih i obrazovanih ljudi poprima obilježja lokalnih govora. U Francuskoj se obrazovanim ljudima ne 
može prepoznati regionalno porijeklo (Desnica-Žerjavić, 2006). U SAD-u nijedan regionalni govor ne izaziva stereotipnu reakciju (Davis, 1970), ali izgovor etničkih zajednica izaziva, naročito ako njihov govor asocira na niži socioekonomski status.

\section{CILJ ISTRAŽIVANJA, ISPITANICI I INSTRUMENTI}

Ovim se radom nastojalo opisati mišljenje neizvornih govornika hrvatskog jezika o vlastitim odstupanjima u izgovoru te su postavljene sljedeće hipoteze: H1: Govornici srodnih jezika imat će sličnije rezultate samoprocjene.

H2: Govornici srodnih jezika s hrvatskim navest će manje varijabli vlastitih odstupanja.

Pod srodnim se jezikom ovdje podrazumijeva pripadnost jezika istoj jezičnoj skupini, tj. istoj potporodici.

U istraživanju su sudjelovala 73 ispitanika različitih razina poznavanja hrvatskog jezika i različitih prvih jezika kao što je navedeno u tablici 1 . Svi su polaznici nastave hrvatskog jezika za neizvorne govornike na Croaticumu - centru za hrvatski kao drugi i strani jezik na Filozofskom fakultetu u Zagrebu i upisali su izborni kolegij Govorne vježbe.

Materinski jezici koje govore ispitanici pripadaju u pet porodica $(\mathrm{u}$ suvremenoj lingvistici najprihvaćenija podjela bazirana na povijesnoj srodnosti, a ponekad i na geografskom kriteriju (Škiljan, 1987: 20)) indoeuropskim jezicima, semitsko-hamitskim jezicima, mongolskim, tzv. azijskim jezicima izvan porodica te kinesko-tibetskoj porodici. S obzirom na $\mathrm{H} 1$ pretpostavljeno je da je hrvatski kao dio indoeuropskih jezika manje srodan s ostalim navedenim porodicama, a unutar indoeuropske porodice srodniji je sa slavenskim jezicima nego s germanskim, albanskim i romanskim jezicima.

Naizgled banalnu hipotezu da će slične rezultate samoprocjene imati govornici srodnih jezika postavljamo s obzirom na vrlo argumentirane Sapirove tvrdnje (2013: 154) o postojanju tendencije "da se glasovi ili pojedini načini artikulacije šire kontinuiranim područjima na isti način kao što elementi kulture zrače iz nekoga zemljopisnog središta"i da nisu nužno povezani samo s genetskim srodstvom. 
Tablica 1. Podaci o ispitanicima

\begin{tabular}{|l|l|l|l|l|l|l|}
\hline & Jezici & A1 & B1.1 & B1.2 & B2 & Ukupno jezici \\
\hline 1. & arapski & 2 & 1 & 0 & 0 & 3 \\
\hline 2. & češki & 2 & 0 & 0 & 0 & 2 \\
\hline 3. & njemački & 3 & 0 & 0 & 1 & 3 \\
\hline 4. & njemački i albanski & 0 & 0 & 0 & 1 & 1 \\
\hline 5. & španjolski & 15 & 4 & 2 & 0 & 21 \\
\hline 6. & portugalski & 8 & 0 & 0 & 0 & 8 \\
\hline 7. & japanski & 1 & 0 & 0 & 0 & 1 \\
\hline 8. & talijanski & 1 & 0 & 0 & 3 & 1 \\
\hline 9. & engleski & 10 & 0 & 0 & 1 & 11 \\
\hline 10. & kineski & 1 & 0 & 7 & 1 & 9 \\
\hline 11. & mongolski & 1 & 0 & 0 & 0 & 1 \\
\hline 12. & rumunjski & 0 & 2 & 1 & 0 & 3 \\
\hline 13. & poljski & 0 & 0 & 1 & 1 & 2 \\
\hline 14. & ruski & 0 & 0 & 2 & 0 & 2 \\
\hline 15. & danski & 0 & 0 & 0 & 1 & 1 \\
\hline Ukupno & & 44 & 7 & 13 & 9 & \\
\hline
\end{tabular}

Svi su ispitanici ispunili upitnik samoprocjene s demografskim podacima. Njihova je dob bila u rasponu od 19 do 76 godina. Govore 15 različitih materinskih jezika. Abecednim redom njihov je J1 albanski, arapski, češki, danski, engleski, japanski, kineski, mongolski, njemački, poljski, portugalski, rumunjski, ruski, španjolski i talijanski. Najviše je bilo govornika kojima je španjolski materinski jezik. Razina znanja ispitanika varira od apsolutnih početnika do B2 razine prema Zajedničkom europskom referentnom okviru (ZEROJ). Najviše je bilo početnika $(\mathrm{N}=44)$, sedmero ispitanika poznaje hrvatski jezik na razini B1.1, na razini B1.2 bilo je 13 ispitanika, a na razini B2 njih 9. Ako su ispitanici smatrali da njihov izgovor odstupa od standardnog izgovora, stavili su ispod oznake određene varijable oznaku ", ${ }^{\prime \prime}$. Varijable koje su ispitanici procjenjivali bile su intonacije, vokali, konsonanti i naglasci, a mogli su dodati i druge varijable prema vlastitoj procjeni. Te su varijable odabrane budući da su se izdvojile u ranijim radovima perceptivne analize (primjerice, $\mathrm{u}$ istraživanju odstupanja u izgovoru neizvornih govornika (Banković-Mandić, 2012) stručni su procjenitelji opisivali odstupanja u izgovoru neizvornih govornika upravo tim varijablama). Budući da su ispitanici bili neizvorni govornici hrvatskog jezika kojima pojam klasičnog izgovora, općeprihvaćenog izgovora i sl. nisu poznati, oni su dobili samo upute da navedu odstupanja u odnosu na hrvatski jezik.

Svoj su izgovor u cjelini ispitanici procjenjivali ocjenama 1-5, gdje ocjena 1 označava vlastiti izgovor hrvatskog jezika kao posve neprihvatljiv, ocjena 2 označava da je izgovor uglavnom neprihvatljiv, ocjena 3 označava prihvatljiv izgovor, ocjena 4 vrlo prihvatljiv u usporedbi sa svijesti o izgovoru hrvatskog kao J1, ocjena 5 znači da je izgovor vrlo sličan ili isti kao u hrvatskome kao J1. 


\section{REZULTATI ANALIZE UPITNIKA}

Rezultati upitnika prikazat će se prema razinama poznavanja hrvatskog jezika. Za početnu razinu podaci o varijablama donose se $u$ tablici 2 , a $u$ tablici 3 prikazani su zbirni podaci. Oznaka V znači vokali, $\mathrm{K}$ - konsonanti, NAG - naglasci, INT - intonacije, DR - druge varijable koje su ispitanici dodali, a nisu bile ponuđene.

Tablica 2. Ispitanici - početnici (Govorne vježbe 1)

\begin{tabular}{|c|c|c|c|c|c|c|c|c|c|c|c|}
\hline \multirow[t]{2}{*}{ R. br. } & \multirow[t]{2}{*}{ Ispitanik } & \multirow[t]{2}{*}{ Dob } & \multirow[t]{2}{*}{ Spol } & \multirow{2}{*}{$\begin{array}{l}\text { Razina } \\
\text { HJ }\end{array}$} & \multirow{2}{*}{$\begin{array}{l}\text { Materinski } \\
\text { jezik/ci }\end{array}$} & \multirow{2}{*}{\begin{tabular}{|l} 
Izgovor \\
(samopro- \\
cjena)
\end{tabular}} & \multicolumn{5}{|c|}{ Varijable } \\
\hline & & & & & & & V & $\mathbf{K}$ & NAG & INT & DR \\
\hline 1. & S.S. & 39 & Ž & A1 & arapski & 1 & + & + & + & + & \\
\hline 2. & L.G. & 24 & $\check{Z}$ & A1 & češki & 3 & & & + & + & \\
\hline 3. & S.S. & 25 & Ž & A1 & njemački & 3 & & $n j, l j$ & & & č/ć \\
\hline 4. & L.P. & 24 & $\check{Z}$ & A1 & španjolski & 3 & & $\begin{array}{l}\text { d, dž, } \\
\text { nj, č,ć }\end{array}$ & + & + & \\
\hline 5. & M.G. & 36 & $\check{Z}$ & A1 & španjolski & 3 & & + & & & \\
\hline 6. & L.S. & 35 & $\check{Z}$ & A1 & španjolski & 2 & & + & + & + & \\
\hline 7. & S.S. & 41 & $\mathrm{M}$ & A1+ & portugalski & 2 & + & + & + & + & \\
\hline 8. & R.A. & 24 & $\check{Z}$ & A1 & španjolski & 3 & + & & & + & \\
\hline 9. & L.S. & 32 & Ž & A1 & španjolski & 1 & + & + & + & + & \\
\hline 10. & S.K. & 28 & $\check{Z}$ & A1 & španjolski & & + & + & + & + & \\
\hline 11. & T.L. & 28 & $\mathrm{M}$ & A1 & $\begin{array}{l}\text { španjolski } \\
(\text { hrv u } \\
\text { djetinjstvu) }\end{array}$ & 4 & & + & + & + & \\
\hline 12. & A.M. & 25 & $\mathrm{M}$ & A1 & španjolski & 3 & & + & + & + & \\
\hline 13. & C.P. & 31 & $\mathrm{M}$ & A1 & španjolski & 2 & & + & & + & \\
\hline 14. & D.K. & 25 & $\check{Z}$ & A1+ & španjolski & 2 & & + & + & & \\
\hline 15. & F.S. & 44 & $\mathrm{M}$ & A1 & portugalski & 1 & + & + & + & + & \\
\hline 16. & F.S. & 20 & $\check{Z}$ & A1 & portugalski & 2 & + & + & + & + & \\
\hline 17. & D.S. & 52 & Ž & A1 & portugalski & 1 & + & + & + & + & \\
\hline 18. & S.S. & 52 & Ž & A1 & portugalski & & + & + & + & + & \\
\hline 19. & W.S. & 46 & $\mathrm{M}$ & A1 & portugalski & 1 & + & + & + & + & \\
\hline 20. & J.C. & 62 & $\mathrm{M}$ & A1 & portugalski & 1 & + & + & + & + & \\
\hline 21. & M.O. & 60 & Ž & A1 & portugalski & 1 & + & + & + & + & \\
\hline 22. & K.K. & 43 & $\mathrm{M}$ & A1 & japanski & 1 & + & + & + & + & \\
\hline 23. & A.A. & 36 & $\mathrm{M}$ & A1 & $\begin{array}{l}\text { arapski (̌̌ } \\
\text { hrv) }\end{array}$ & 3 & + & + & + & + & \\
\hline 24. & A.A. & 29 & $\mathrm{M}$ & A1 & talijanski & 1 & + & + & + & + & $\begin{array}{l}\text { č, ć, d, } \\
\mathrm{dž}\end{array}$ \\
\hline 25. & J.P. & 26 & $M$ & A1 & španjolski & 3 & & & + & + & \\
\hline 26. & N.K. & 36 & $\mathrm{M}$ & A1 & španjolski & 2 & + & + & + & + & \\
\hline 27. & L.P. & 36 & $M$ & A1 & španjolski & 2 & & + & + & + & \\
\hline 28. & A.C. & 26 & $\check{Z}$ & A1 & španjolski & 3 & & + & + & + & \\
\hline 29. & M.G. & 22 & $M$ & A1 & engleski & 1 & + & + & + & + & \\
\hline 30. & A.L. & 19 & $\check{Z}$ & A1 & engleski & 1 & + & + & + & + & \\
\hline
\end{tabular}




\begin{tabular}{|c|c|c|c|c|c|c|c|c|c|c|c|}
\hline 31. & M.Š. & 21 & $\mathrm{M}$ & A1 & $\begin{array}{l}\text { engleski } \\
\text { (roditelji } \\
\text { hrv J1) }\end{array}$ & 3 & + & + & + & + & \\
\hline 32. & J.C. & 23 & Ž & A1 & engleski & 1 & + & + & + & + & \\
\hline 33. & J.U. & 26 & $M$ & A1 & $\begin{array}{l}\text { engleski } \\
\text { (baka i djed } \\
\text { hrv J1) }\end{array}$ & 2 & & + & + & + & \\
\hline 34. & P.G. & 29 & $\mathrm{M}$ & A1 & engleski & 1 & + & & + & + & \\
\hline 35. & D.C. & 30 & $M$ & A1 & $\begin{array}{l}\text { engleski (6 } \\
\text { mj u RH, } 3 \\
\text { mj uči HJ) }\end{array}$ & 3 & & & + & + & \\
\hline 36. & K.C. & 27 & $Z \check{Z}$ & A1 & $\begin{array}{l}\text { eng (2 mj } \\
\text { u RH, } 4 \text { mj } \\
\text { uči HJ) }\end{array}$ & 3 & + & & + & + & \\
\hline 37. & W.W. & 34 & M & A1 & kineski & 3 & & & + & + & \\
\hline 38. & K.M. & 22 & Ž & A1 & portugalski & 1 & & & + & + & \\
\hline 39. & O.S. & 24 & Ž & A1 & češki & 3 & & & + & + & \\
\hline 40. & R.S. & 25 & Ž & A1 & $\begin{array}{l}\text { njemački } \\
\text { (rođaci } \\
\text { Hrvati) }\end{array}$ & 1 & + & + & + & + & \\
\hline 41. & R.A. & 29 & Ž & A1+ & $\begin{array}{l}\text { eng ( } 4 \text { mj } \\
\text { uči HJ) }\end{array}$ & 4 & & & + & + & palatali \\
\hline 42. & A.O. & 23 & Ž & A1 & mongolski & 2 & & + & + & + & \\
\hline 43. & N.A. & 21 & $\mathrm{M}$ & A1 & $\begin{array}{l}\text { njemački (4 } \\
\text { mj uči HJ) }\end{array}$ & 2 & + & + & + & + & \\
\hline 44. & D. H. & 20 & $\mathrm{M}$ & A1 & $\begin{array}{l}\text { engleski } \\
\text { (mama } \\
\text { Hrvatica) }\end{array}$ & 3 & & & + & + & \\
\hline Ukupno & & 31 & & & & 2,1 & 24 & $33+2$ & 40 & 42 & 3 \\
\hline
\end{tabular}

Iz tablice 2 uočljiv je podatak da oni ispitanici koji dulje uče hrvatski višim ocjenama procjenjuju svoj izgovor (ti su ispitanici označeni svijetloosjenčanim redovima) - primjerice, ispitanik pod rednim brojem 11 učio je hrvatski u djetinjstvu i svoj izgovor ocijenio je ocjenom 4, ispitanica pod red. br. 41 učila je hrvatski 4 mjeseca i ocijenila svoj izgovor ocjenom 4. Prosječna ocjena početnika je $2(2,1)$, a oni koji su hrvatski slušali u djetinjstvu ili netko njima blizak govori hrvatski (majka, supruga i sl.) svoj izgovor procjenjuju višim ocjenama od prosjeka (ispitanik 23, 31, 44). Zanimljivo je da ispitanica čiji rođaci govore hrvatski svoj izgovor procjenjuje jedinicom (ispitanica red. br. 40, red je tamnije osjenčan u tablici). To može značiti da ju u pokušaju komunikacije na hrvatskom oni često ispravljaju ili da ju ne razumiju kad govori, kao ni ona njih.

Kao što se može iščitati u tablici 3 prosječna je dob ispitanika početne razine 31 (u rasponu od 19-62) i oni su svoj izgovor u odnosu na druge razine procijenili najnižom ocjenom. Kao najveći problem (42 odgovora) izdvojili su intonacije, a kao najmanji izgovor vokala. U izgovoru konsonanata samo dvoje ispitanika specificirano navode koji su konsonanti problem - jedan 
izdvaja sve palatalne glasove, drugi samo $n j$ i $l j$, a njih 33 nije specificiralo koji su im konsonanti problematični pa je u tablicama tako i navedeno (33+2). Pod druge varijable neki ispitanici navode također palatale kao poseban problem te (ne)razlikovanje glasova č i ć te $d \check{\text { i d. }}$

Tablica 3. Zbirni podaci o varijablama za govornike hrvatskog jezika na početnoj razini

\begin{tabular}{|l|l|l|l|l|l|l|}
\hline \multirow{2}{*}{ Dob } & Izgovor (samoprocjena) & \multicolumn{6}{|l|}{ Varijable } & \multicolumn{6}{l|}{} \\
\cline { 3 - 7 } & & V & K & NAG & INT & DR \\
\hline $\begin{array}{l}31 \\
(19-62)\end{array}$ & 2,1 & 24 & $33+2$ & 40 & 42 & 3 \\
\hline
\end{tabular}

Podaci o govornicima razine B1.1 donose se u tablici 4, a zbirni za govornike razine B1.1 u tablici 5 .

Tablica 4. Ispitanici - Razina B1 (Govorne vježbe 2)

\begin{tabular}{|c|c|c|c|c|c|c|c|c|c|c|c|}
\hline \multirow[t]{2}{*}{ R. br. } & \multirow[t]{2}{*}{ Ispitanik } & \multirow[t]{2}{*}{ Dob } & \multirow[t]{2}{*}{ Spol } & \multirow{2}{*}{\begin{tabular}{|l|} 
Razina \\
HJ
\end{tabular}} & \multirow{2}{*}{$\begin{array}{l}\text { Materinski } \\
\text { jezik/ci }\end{array}$} & \multirow{2}{*}{\begin{tabular}{|l|} 
Izgovor 1-5 \\
(samoprocjena)
\end{tabular}} & \multicolumn{5}{|c|}{ Varijable } \\
\hline & & & & & & & V & K & NAG & INT & DR \\
\hline 1. & S.A. & 31 & $M$ & B1.1 & arapski & 2 & + & + & & & \\
\hline 2. & F.C. & 31 & $\check{Z}$ & B1 & španjolski & 2 & & + & + & + & \\
\hline 3. & A.B. & 31 & Ž & B1.1 & španjolski & 2 & & + & + & + & \\
\hline 4. & M.F. & 26 & Ž & B1.1 & španjolski & 1 & & + & + & + & \\
\hline 5. & R.R. & 20 & Ž & B1.1 & španjolski & 3 & & + & & + & \\
\hline 6. & L.V. & 20 & Ž & B1.1 & rumunjski & 3 & & & + & + & \\
\hline 7. & C.L. & 21 & Ž & B1.1 & rumunjski & 3 & & & + & + & \\
\hline Ukup. & & 26 & & & & 2,3 & 1 & 5 & 5 & 6 & \\
\hline
\end{tabular}

Ispitanici razine B1.1 bili su dobno ujednačenija skupina, a prema spolu dominirale su žene. Kao najveći problem izdvajaju intonacije, a najmanji vokale. Jedino govornik arapskog jezika izdvaja vokale kao veći problem. Inače, vokalski sustav španjolskog jezika vrlo je sličan hrvatskom, štoviše formalno identičan (pet vokala koji se prikazuju trokutom) pa su takve procjene očekivane. No, neobično je da kao problem većina ispitanika izdvaja intonacije koje su na ovoj razini posve prihvatljive. Gotovo svi ispitanici kao problem vlastitog izgovora navode naglaske.

Tablica 5. Zbirni podaci o varijablama za govornike hrvatskog jezika na razini B1.1

\begin{tabular}{|c|c|c|c|c|c|c|}
\hline \multirow[t]{2}{*}{ Dob } & \multirow[t]{2}{*}{ Izgovor (samoprocjena) } & \multicolumn{5}{|c|}{ Varijable } \\
\hline & & V & K & NAG & INT & DR \\
\hline 26 & 2,3 & 1 & 5 & 5 & 6 & 0 \\
\hline
\end{tabular}

Podaci o govornicima razine B1.2 donose se $\mathrm{u}$ tablici 6 , a zbirni za govornike razine B1.2 u tablici 7.

Ispitanici ove razine u dobi su od 21 do 49 godina, također dominiraju žene. Od materinskih jezika najprisutniji je kineski jezik i prosječna je ocjena samoprocjene 2,3. Ocjena je jednaka samoprocjeni govornika na razini B1.1. 
Tablica 6. Ispitanici - Razina B1.2 (Govorne vježbe 3)

\begin{tabular}{|c|c|c|c|c|c|c|c|c|c|c|c|}
\hline \multirow{2}{*}{$\begin{array}{l}\text { R. } \\
\text { br. }\end{array}$} & \multirow[t]{2}{*}{ Ispitanik } & \multirow[t]{2}{*}{ Dob } & \multirow[t]{2}{*}{ Spol } & \multirow[t]{2}{*}{ Razina $\mathrm{HJ}$} & \multirow{2}{*}{$\begin{array}{l}\text { Materinski } \\
\text { jezik/ci }\end{array}$} & \multirow{2}{*}{\begin{tabular}{|l|} 
Izgovor \\
(samoprocjena)
\end{tabular}} & \multicolumn{5}{|c|}{ Varijable } \\
\hline & & & & & & & $\mathbf{V}$ & K & NAG & INT & DR \\
\hline 1. & Z.W. & 21 & Ž & B1.2 & kineski & 2 & + & + & + & + & \\
\hline 2. & J.W & 22 & Ž & B1.2 & kineski & 2 & & + & + & + & \\
\hline 3. & Z.Z. & 21 & Ž & B1.2 & kineski & 2 & & & + & + & \\
\hline 4. & F.L. & 22 & $\check{Z}$ & B1.2 & kineski & 2 & & + & + & + & \\
\hline 5. & A.L. & 21 & Ž & B1.2 & kineski & 1 & + & + & + & + & \\
\hline 6. & Y.L. & 22 & $\check{Z}$ & B1.2 & kineski & 2 & + & + & + & + & \\
\hline 7. & G.A. & 33 & Ž & B1.2 & rumunjski & 3 & + & + & + & + & \\
\hline 8. & I.B. & 49 & Ž & B1.2 & ruski & 3 & & & + & + & \\
\hline 9. & N.I. & 35 & $\mathrm{M}$ & B1.2 & španjolski & 3 & + & + & + & + & \\
\hline 10. & A.Z. & 32 & Ž & B1.2 & španjolski & 3 & & & & + & \\
\hline 11. & A.D. & 29 & $\check{Z}$ & B1.2 & ruski & 2 & + & + & + & + & \\
\hline 12. & K.A. & 25 & Ž & B1.2 & poljski & 2 & & & + & + & \\
\hline \multirow[t]{2}{*}{13.} & L.Y. & 25 & $\mathrm{M}$ & B1.2 & kineski & 3 & + & + & + & + & \\
\hline & & 27 & & & & 2,3 & 7 & 9 & 12 & 13 & \\
\hline
\end{tabular}

Tablica 7. Zbirni podaci o varijablama za govornike hrvatskog jezika na razini B1.2

\begin{tabular}{|l|l|l|l|l|l|l|}
\hline \multirow{2}{*}{ Dob } & Izgovor (samoprocjena) & \multicolumn{6}{|l|}{ Varijable } & & V & K & NAG & INT & DR \\
\cline { 3 - 8 } & & 7 & 9 & 12 & 13 & \\
\hline 27 & 2,3 & 7 & 9 &
\end{tabular}

I na razini B1.2. ispitanici kao najveći problem vlastitog izgovora izdvajaju intonacije, ali i naglaske. Gotovo svi govornici kineskog kao J1 izdvajaju sve varijable kao problem. No, neobično je da na ovoj razini isto navodi i ispitanica čiji je J1 ruski, ispitanica čiji je J1 rumunjski te ispitanica čiji je J1 španjolski. I ovdje su kao velik problem izdvojeni naglasci.

Podaci o govornicima razine B2.1 donose se u tablici 8, a zbirni za govornike razine B2.1 u tablici 9. U ovoj je skupini i jedna ispitanica koja poznaje hrvatski jezik na višoj razini od B2, ali je pohađala nastavu Govornih vježba s ovom skupinom. Također, u skupini je i ispitanica koja poznaje hrvatski jezik na nešto nižoj razini (B1.2), ali je zbog fonetsko-fonoloških kompetencija uključena u nastavu Govornih vježba više razine.

Tablica 8. Ispitanici - razina B.2.1. (Govorne vježbe 4)

\begin{tabular}{|c|c|c|c|c|c|c|c|c|c|c|c|}
\hline \multirow[t]{2}{*}{ R. br. } & \multirow[t]{2}{*}{ Ispitanici } & \multirow[t]{2}{*}{ Dob } & \multirow[t]{2}{*}{ Spol } & \multirow{2}{*}{$\begin{array}{l}\text { Razina } \\
\text { hj }\end{array}$} & \multirow{2}{*}{$\begin{array}{l}\text { Materinski } \\
\text { jezik/ci }\end{array}$} & \multirow{2}{*}{\begin{tabular}{|l|} 
Izgovor \\
(samoprocjena)
\end{tabular}} & \multicolumn{5}{|c|}{ Varijable } \\
\hline & & & & & & & V & K & NAG & INT & DR \\
\hline 1. & G.Z. & 24 & Ž & B2.1 & talijanski & 2 & & + & + & + & \\
\hline 2. & J.G. & 25 & Ž & B2.1 & njemački & 3 & & + & + & + & \\
\hline 3. & M.G. & 26 & Ž & B2.1 & talijanski & 3 & & + & + & + & \\
\hline 4. & C.J. & 32 & $\mathrm{M}$ & B2.1 & engleski & 3 & & & & + & \\
\hline 5. & Y.W. & 20 & Ž & B2.1 & kineski & 2 & + & + & + & + & \\
\hline 6. & P.G. & 22 & Ž & B2.2 & poljski & 4 & + & + & + & & \\
\hline 7. & G.M. & 23 & $\bar{Z}$ & B1.2 & njem/alb & 3 & & + & + & + & \\
\hline
\end{tabular}




\begin{tabular}{|l|l|l|l|l|l|l|l|l|l|l|l|}
\hline 8. & M.D. & 76 & M & B2.1 & danski & 1 & & + & + & & \\
\hline 9. & G.P. & 24 & Ž & B2.1 & talijanski & 5 & & & & & $\begin{array}{l}\text { malo } \\
\text { sve }\end{array}$ \\
\hline Ukup. & & $\begin{array}{l}30 \\
(20-76)\end{array}$ & & & & 2,9 & 2 & 7 & 7 & 6 & 1 \\
\hline
\end{tabular}

Tablica 9. Zbirni podaci o varijablama za govornike hrvatskog jezika na razini B2.1

\begin{tabular}{|c|c|c|c|c|c|c|}
\hline \multirow[t]{2}{*}{ Dob } & \multirow[t]{2}{*}{ Izgovor (samoprocjena) } & \multicolumn{5}{|c|}{ Varijable } \\
\hline & & $\mathbf{V}$ & $\mathbf{K}$ & NAG & INT & DR \\
\hline 30 & 2,9 & 2 & 7 & 7 & 6 & 1 \\
\hline
\end{tabular}

Ispitanici su ove razine $\mathrm{u}$ dobi od 20 do 76 godina. Najstariji govornik svoj izgovor procjenjuje najlošijom ocjenom. Skupina je i s obzirom na J1 vrlo heterogena. U ovoj su skupini rezultati samoprocjene najraspršeniji (1-5), prevladava ocjena 3. Konsonanti i naglasci izdvojeni su kao najveći problem, ali u velikom broju i intonacije što je vrlo neobično. Ispitanica koja je svoj izgovor ocijenila najvećom ocjenom također je navela da bi trebala raditi na svim varijablama.

S obzirom na hipotezu imaju li govornici srodnih jezika slične stavove o odstupanjima u hrvatskom jeziku i slične varijable, rezultati samoprocjene izdvojeni su prema J1 ispitanika. Izdvojeni su rezultati samo onih ispitanika čiji je J1 zastupljen s najmanje tri govornika. U tablici 10 prikazani su rezultati govornika čiji je J1 njemački.

Tablica 10. Njemački kao J1 i hrvatski kao J2

\begin{tabular}{|c|c|c|c|c|c|c|c|c|c|c|c|}
\hline \multirow[t]{2}{*}{ R.br. } & \multirow[t]{2}{*}{ Ispitanik } & \multirow[t]{2}{*}{ Dob } & \multirow[t]{2}{*}{ Spol } & \multirow[t]{2}{*}{ Razina HJ } & \multirow{2}{*}{$\begin{array}{l}\text { Materinski } \\
\text { jezik/ci }\end{array}$} & \multirow{2}{*}{\begin{tabular}{|l|}
$\begin{array}{l}\text { Izgovor } \\
\text { (samoprocjena) }\end{array}$ \\
\end{tabular}} & \multicolumn{5}{|c|}{ Varijable } \\
\hline & & & & & & & V & K & NAG & INT & DR \\
\hline 1. & R.S. & 25 & $\check{Z}$ & A1 & $\begin{array}{l}\text { njemački } \\
\text { (rođaci } \\
\text { Hrvati) } \\
\end{array}$ & 1 & + & + & + & + & \\
\hline 2. & N.A. & 21 & $\mathrm{M}$ & A1 & $\begin{array}{l}\text { njemački (4 } \\
\text { mj uči HJ) }\end{array}$ & 2 & + & + & + & + & \\
\hline 3. & J.G. & 25 & Ž & B2 & njemački & 3 & & + & + & + & \\
\hline
\end{tabular}

Svi ispitanici čiji je J1 njemački smatraju da njihov izgovor konsonanata, naglasaka i intonacija u hrvatskom kao J2 nije zadovoljavajući te da trebaju vježbati navedene varijable. Ispitanica napredne razine (B2) smatra da su njezini vokali dobri, a ostale varijable treba korigirati.

Rezultati samoprocjene ispitanika kojima je engleski J1 donose se $u$ tablici 11. 
Tablica 11. Engleski kao J1 i hrvatski kao J2

\begin{tabular}{|c|c|c|c|c|c|c|c|c|c|c|c|}
\hline \multirow{2}{*}{$\begin{array}{l}\text { R. } \\
\text { br. }\end{array}$} & \multirow[t]{2}{*}{ Ispitanik } & \multirow[t]{2}{*}{ Dob } & \multirow[t]{2}{*}{ Spol } & \multirow[t]{2}{*}{ Razina HJ } & \multirow{2}{*}{$\begin{array}{l}\text { Materinski } \\
\text { jezik/ci }\end{array}$} & \multirow{2}{*}{\begin{tabular}{|l|} 
Izgovor \\
(samoprocjena)
\end{tabular}} & \multicolumn{5}{|c|}{ Varijable } \\
\hline & & & & & & & $\mathbf{V}$ & K & NAG & INT & DR \\
\hline 1. & M.G. & 22 & M & A1 & engleski & 1 & + & + & + & + & \\
\hline 2. & A.L. & 19 & Ž & A1 & engleski & 1 & + & + & + & + & \\
\hline 3. & M.Š. & 21 & $M$ & A1 & $\begin{array}{l}\text { engleski } \\
\text { (roditelji } \\
\text { hrv J1) }\end{array}$ & 3 & + & + & + & + & \\
\hline 4. & J.C. & 23 & Ž & A1 & engleski & 1 & + & + & + & + & \\
\hline 5. & J.U. & 26 & $\mathrm{M}$ & A1 & $\begin{array}{l}\text { engleski } \\
\text { (baka i djed } \\
\text { hrv J1) }\end{array}$ & 2 & & + & + & + & \\
\hline 6. & P.G. & 29 & $\mathrm{M}$ & A1 & engleski & 1 & + & & + & + & \\
\hline 7. & D.C. & 30 & $\mathrm{M}$ & A1 & $\begin{array}{l}\text { engleski (6 } \\
\text { mj u RH, } 3 \\
\text { mj uči HJ) }\end{array}$ & 3 & & & + & + & \\
\hline 8. & K.C. & 27 & $\check{Z}$ & A1 & $\begin{array}{l}\text { eng (2 mj } \\
\text { u RH, } 4 \text { mj } \\
\text { uči HJ) }\end{array}$ & 3 & + & & + & + & \\
\hline 9. & R.A. & 29 & $\check{Z}$ & A1+ & $\begin{array}{l}\text { eng }(4 \mathrm{mj} \\
\text { uči HJ) }\end{array}$ & 4 & & & + & + & palatali \\
\hline 10. & D. H. & 20 & $\mathrm{M}$ & A1 & $\begin{array}{l}\text { engleski } \\
\text { (mama } \\
\text { Hrvatica) }\end{array}$ & 3 & & & + & + & \\
\hline 11. & C.J. & 32 & $\mathrm{M}$ & B2 & engleski & 3 & & & & + & \\
\hline
\end{tabular}

Svi ispitanici kojima je J1 engleski, smatraju da trebaju raditi na intonacijama. To što početnici razmišljaju o svojim intonacijama kao nedovoljno dobrima može se objasniti općenitom početničkom nesigurnošću, no neobično je što isto misli ispitanik visoke razine hrvatskog jezika. Obično govornici engleskog jezika, ukoliko nisu imali vježbe korekcije izgovora, mogu imati odstupanja u izgovoru glasova i realizaciji mjesta naglaska, ali ne i u intonacijama. Više ispitanika misli da treba raditi na vokalima nego na izgovoru konsonanata. Oni koji hrvatski uče dulje (iako ga nisu naučili pa su na početnoj razini hrvatskog nakon inicijalnog testiranja) obično smatraju svoj izgovor boljim od onih kojima je ovo sam početak učenja. Osim brojčane ocjene to pokazuju i manjim brojem varijabli, najčešće ne navode vokale kao sporne. MOD ocjena samoprocjene ovih govornika (premda su početnici) iznosi 3.

Rezultati samoprocjene ispitanika kojima je španjolski J1 donose se $\mathrm{u}$ tablici 12. 
Tablica 12. Španjolski kao J1 i hrvatski kao J2

\begin{tabular}{|c|c|c|c|c|c|c|c|c|c|c|c|}
\hline \multirow{2}{*}{$\begin{array}{l}\text { R. } \\
\text { br. }\end{array}$} & \multirow[t]{2}{*}{ Ispitanik } & \multirow[t]{2}{*}{ Dob } & \multirow[t]{2}{*}{ Spol } & \multirow{2}{*}{$\begin{array}{l}\text { Razina } \\
\text { HJ }\end{array}$} & \multirow{2}{*}{$\begin{array}{l}\text { Materinski } \\
\text { jezik/ci }\end{array}$} & \multirow{2}{*}{$\begin{array}{l}\text { Izgovor } \\
\text { (samoprocjena) }\end{array}$} & \multicolumn{5}{|c|}{ Varijable } \\
\hline & & & & & & & $\mathrm{V}$ & $\mathbf{K}$ & NAG & INT & DR \\
\hline 1. & L.P. & 24 & Ž & A1 & španjolski & 3 & & $\begin{array}{l}\text { d, dž, } \\
\text { nj, č,ć }\end{array}$ & + & + & \\
\hline 2. & M.G. & 36 & $Z \check{Z}$ & A1 & španjolski & 3 & & + & & & \\
\hline 3. & L.S. & 35 & $Z \check{Z}$ & A1 & španjolski & 2 & & + & + & + & \\
\hline 4. & R.A. & 24 & $Z \check{Z}$ & A1 & španjolski & 3 & + & & & + & \\
\hline 5. & L.S. & 32 & $Z \check{Z}$ & A1 & španjolski & 1 & + & + & + & + & \\
\hline 6. & S.K. & 28 & $Z \check{Z}$ & A1 & španjolski & & + & + & + & + & \\
\hline 7. & T.L. & 28 & $\mathrm{M}$ & A1 & $\begin{array}{l}\text { španjolski } \\
\text { (hrv u } \\
\text { djetinjstvu) }\end{array}$ & 4 & & + & + & + & \\
\hline 8. & A.M. & 25 & $\mathrm{M}$ & A1 & španjolski & 3 & & + & + & + & \\
\hline 9. & C.P. & 31 & $M$ & A1 & španjolski & 2 & & + & & + & \\
\hline 10. & D.K. & 25 & $Z$ & A1.2 & španjolski & 2 & & + & + & & \\
\hline 11. & J.P. & 26 & $\mathrm{M}$ & A1 & španjolski & 3 & & & + & + & \\
\hline 12. & N.K. & 36 & $\mathrm{M}$ & A1 & španjolski & 2 & + & + & + & + & \\
\hline 13. & L.P. & 36 & $M$ & A1 & španjolski & 2 & & + & + & + & \\
\hline 14. & A.C. & 26 & Ż & A1 & španjolski & 3 & & + & + & + & \\
\hline 15. & F.C. & 31 & $Z$ & B1 & španjolski & 2 & & + & + & + & \\
\hline 16. & A.B. & 31 & Ž & B1 & španjolski & 2 & & + & + & + & \\
\hline 17. & M.F. & 26 & Ž & B1 & španjolski & 1 & & + & + & + & \\
\hline 18. & R.R. & 20 & Ž & B1 & španjolski & 3 & & + & & + & \\
\hline 19. & N.I. & 35 & $\mathrm{M}$ & B1.2 & španjolski & 3 & + & + & + & + & \\
\hline 20. & A.Z. & 32 & Ż & B1.2 & španjolski & 3 & & & & + & \\
\hline
\end{tabular}

Govornici kojima je španjolski J1 uglavnom navode da je njihov problem izgovor konsonanata i intonacije. Tako je izjavilo 18 od 20 ispitanika. Ukupno 15 ispitanika izdvojilo je i naglaske. Samo petero ispitanika navodi da bi trebali korigirati svoje vokale. Kao što je već rečeno, španjolski se vokalski sustav opisuje jednako kao i hrvatski pa se mogu očekivati tek neznatna odstupanja u izgovoru vokala. Tri četvrtine ispitanika smatra da treba korigirati svoje naglaske. Prosječna ocjena samoprocjene zaokružena na jednu decimalu španjolskih govornika je 2,5.

Rezultati samoprocjene ispitanika kojima je portugalski J1 donose se u tablici 13. 
Tablica 13. Portugalski kao J1 i hrvatski kao J2

\begin{tabular}{|c|c|c|c|c|c|c|c|c|c|c|c|}
\hline \multirow{2}{*}{$\begin{array}{l}\text { R. } \\
\text { br. }\end{array}$} & \multirow[t]{2}{*}{ Ispitanik } & \multirow[t]{2}{*}{ Dob } & \multirow[t]{2}{*}{ Spol } & \multirow{2}{*}{\begin{tabular}{|l|} 
Razina \\
HJ
\end{tabular}} & \multirow{2}{*}{$\begin{array}{l}\text { Materinski } \\
\text { jezik/ci }\end{array}$} & \multirow{2}{*}{$\begin{array}{l}\begin{array}{l}\text { Izgovor } \\
\text { (samoprocjena) }\end{array} \\
\end{array}$} & \multicolumn{5}{|c|}{ Varijable } \\
\hline & & & & & & & $\mathbf{V}$ & $\mathrm{K}$ & NAG & INT & DR \\
\hline 1. & S.S. & 41 & $\mathrm{M}$ & A1+ & portugalski & 2 & + & + & + & + & \\
\hline 2. & F.S. & 44 & $\mathrm{M}$ & A1 & portugalski & 1 & + & + & + & + & \\
\hline 3. & F.S. & 20 & Ž & A1 & portugalski & 2 & + & + & + & + & \\
\hline 4. & D.S. & 52 & Ž & A1 & portugalski & 1 & + & + & + & + & \\
\hline 5. & S.S. & 52 & Ž & A1 & portugalski & & + & + & + & + & \\
\hline 6. & W.S. & 46 & $M$ & A1 & portugalski & 1 & + & + & + & + & \\
\hline 7. & J.C. & 62 & $\mathrm{M}$ & A1 & portugalski & 1 & + & + & + & + & \\
\hline 8. & M.O. & 60 & Ž & A1 & portugalski & 1 & + & + & + & + & \\
\hline 9. & K.M. & 22 & Ž & A1 & portugalski & 1 & & & + & + & \\
\hline
\end{tabular}

Svi su ispitanici portugalskog kao J1 bili početnici i svi su osim jednog naveli da su u njihovu izgovoru problematične sve ponuđene varijable. Prosječna je ocjena koju daju svojem izgovoru nedovoljna, samo dvoje ispitanika svoj izgovor procjenjuje ocjenom 2.

Rezultati samoprocjene ispitanika kojima je talijanski J1 donose se $\mathrm{u}$ tablici 14 .

Tablica 14. Talijanski kao J1 i hrvatski kao J2

\begin{tabular}{|c|c|c|c|c|c|c|c|c|c|c|c|}
\hline \multirow{2}{*}{$\begin{array}{l}\text { R. } \\
\text { br. }\end{array}$} & \multirow[t]{2}{*}{ Ispitanik } & \multirow[t]{2}{*}{ Dob } & \multirow[t]{2}{*}{ Spol } & \multirow{2}{*}{\begin{tabular}{|l|} 
Razina \\
HJ
\end{tabular}} & \multirow{2}{*}{$\begin{array}{l}\text { Materinski } \\
\text { jezik/ci }\end{array}$} & \multirow{2}{*}{\begin{tabular}{|l} 
Izgovor \\
(samoprocjena)
\end{tabular}} & \multicolumn{5}{|c|}{ Varijable } \\
\hline & & & & & & & V & K & NAG & INT & DR \\
\hline 1. & A.A. & 29 & $\mathrm{M}$ & A1 & talijanski & 1 & + & + & + & + & $\begin{array}{l}\text { č, ć, d, } \\
\mathrm{dž}\end{array}$ \\
\hline 2. & G.Z. & 24 & $Z \check{Z}$ & B2 & talijanski & 2 & & + & + & + & \\
\hline 3. & M.G. & 26 & $\check{Z}$ & B2 & talijanski & 3 & & + & + & + & \\
\hline 4. & G.P. & 24 & $Z \check{Z}$ & B2 & talijanski & 5 & & & & & $\begin{array}{l}\text { malo } \\
\text { sve }\end{array}$ \\
\hline
\end{tabular}

Među ispitanicima kojima je talijanski J1 dominiraju govornici visoke razine i njihova je prosječna ocjena samoprocjene 3,3. Ispitanik početne razine svoj je izgovor ocijenio negativnom ocjenom. Kao problematične varijable ispitanici razine B2 navode sve varijable osim vokala, a ispitanik početne razine i vokale.

Rezultati samoprocjene ispitanika kojima je neki slavenski jezik J1 donose se $\mathrm{u}$ tablici 15.

Tablica 15. Slavenski jezici (zbirno) kao J1 i hrvatski kao J2

\begin{tabular}{|c|c|c|c|c|c|c|c|c|c|c|c|}
\hline \multirow[t]{2}{*}{ R.br. } & \multirow[t]{2}{*}{ Ispitanik } & \multirow[t]{2}{*}{ Dob } & \multirow[t]{2}{*}{ Spol } & \multirow{2}{*}{\begin{tabular}{|l} 
Razina \\
HJ
\end{tabular}} & \multirow{2}{*}{$\begin{array}{l}\text { Materinski } \\
\text { jezik/ci }\end{array}$} & \multirow{2}{*}{\begin{tabular}{|l|} 
Izgovor \\
(samoprocjena)
\end{tabular}} & \multicolumn{5}{|c|}{ Varijable } \\
\hline & & & & & & & $\bar{V}$ & $\mathrm{~K}$ & NAG & INT & DR \\
\hline 1. & L.G. & 24 & $\check{Z}$ & A1 & češki & 3 & & & + & + & \\
\hline 2. & O.S. & 24 & $\check{Z}$ & A1 & češki & 3 & & & + & + & \\
\hline 3. & I.B. & 49 & $\check{Z}$ & B1.2 & ruski & 3 & & & + & + & \\
\hline 4. & A.D. & 29 & $\check{Z}$ & B1.2 & ruski & 2 & + & + & + & + & \\
\hline 5. & K.A. & 25 & $\check{Z}$ & B1.2 & poljski & 2 & & & + & + & \\
\hline 6. & P.G. & 22 & $\check{Z}$ & B2.2 & poljski & 4 & + & + & + & & \\
\hline
\end{tabular}


Od slavenskih jezika u skupini su bili zastupljeni češki, ruski i poljski govornici. Svi govornici slavenskih jezika smatraju da imaju najviše problema s naglascima, a gotovo svi misle da imaju problema i s intonacijama. Trećina smatra da treba raditi na vokalima i na izgovoru konsonanata. Češki govornici zadovoljni su svojim izgovorom vokala i konsonanata. MOD vrijednost ocjene samoprocjene slavenskih govornika je 3, a prosječna ocjena 2,8. Ispitanica najviše razine poznavanja hrvatskog jezika svoj je izgovor ocijenila najvišom ocjenom, ali je svejedno navela da treba raditi na izgovoru vokala, konsonanata i naglascima.

Rezultati samoprocjene ispitanika kojima je kineski jezik J1 donose se $\mathrm{u}$ tablici 16.

Tablica 16. Kineski kao J1 i hrvatski kao J2

\begin{tabular}{|c|c|c|c|c|c|c|c|c|c|c|c|}
\hline \multirow{2}{*}{$\begin{array}{l}\text { R. } \\
\text { br. }\end{array}$} & \multirow[t]{2}{*}{ Ispitanik } & \multirow[t]{2}{*}{ Dob } & \multirow[t]{2}{*}{ Spol } & \multirow{2}{*}{\begin{tabular}{|l} 
Razina \\
HJ
\end{tabular}} & \multirow{2}{*}{$\begin{array}{l}\text { Materinski } \\
\text { jezik/ci }\end{array}$} & \multirow{2}{*}{\begin{tabular}{|l} 
Igovor \\
(samoprocjena)
\end{tabular}} & \multicolumn{5}{|c|}{ Varijable } \\
\hline & & & & & & & V & K & NAG & INT & DR \\
\hline 1. & Z.W. & 21 & Ž & B1.2 & kineski & 2 & + & + & + & + & \\
\hline 2. & J.W & 22 & $Z \check{Z}$ & B1.2 & kineski & 2 & & + & + & + & \\
\hline 3. & Z.Z. & 21 & Ž & B1.2 & kineski & 2 & & & + & + & \\
\hline 4. & F.L. & 22 & Ž & B1.2 & kineski & 2 & & + & + & + & \\
\hline 5. & A.L. & 21 & Ž & B1.2 & kineski & 1 & + & + & + & + & \\
\hline 6. & Y.L. & 22 & Ž & B1.2 & kineski & 2 & + & + & + & + & \\
\hline 7. & L.Y. & 25 & $M$ & B1.2 & kineski & 3 & + & + & + & + & \\
\hline 8. & Y.W. & 20 & $\check{Z}$ & B2 & kineski & 2 & + & + & + & + & \\
\hline
\end{tabular}

Svi kineski govornici kao najveće probleme u svojem izgovoru navode naglaske i intonacije, a gotovo svi navode i izgovor konsonanata. Svi su kineski jezik učili u Pekingu, a u Hrvatskoj su jedan semestar na studentskoj razmjeni i prema inicijalnom testu poznaju hrvatski jezik na razini B1-B2 prema ZEROJ-u. Trećina ispitanika nije zadovoljna svojim izgovorom vokala. Svoj su izgovor ocijenili ocjenom 2.

\section{ZAKLJUČNE NAPOMENE}

Analizom rezultata možemo zaključiti da su obje hipoteze uglavnom potvrđene. Hipoteza da govornici srodnih jezika imaju sličnije rezultate samoprocjene uglavnom je potvrđena za portugalske, španjolske, njemačke, talijanske, kineske i slavenske govornike, ali govornici engleskog kao J1 nisu dali ujednačene ocjene samoprocjene svojeg izgovora za sve varijable, ali jesu za intonacije - svi misle da moraju vježbati intonacije u hrvatskom kao J2. Govornici njemačkog jezika kao J2 naveli su da u hrvatskom jeziku trebaju vježbati intonacije te izgovor konsonanata i naglaske. Govornici španjolskog kao J1 uglavnom misle da trebaju uvježbavati izgovor konsonanata, intonacije i naglaske, ali ne i vokale. Tako misle i govornici talijanskog jezika kao J1. Govornici portugalskog jezika smatraju da trebaju korigirati sve ponuđene 
varijable. Govornici slavenskih jezika smatraju da u hrvatskom kao J2 trebaju vježbati naglaske. Kineski govornici smatraju da trebaju u svojem izgovoru korigirati konsonante, naglaske i intonacije.

Druga hipoteza da će govornici srodnih jezika s hrvatskim navesti manje varijabli vlastitih odstupanja također je djelomično potvrđena. Govornici drugih slavenskih jezika, naime, naveli su manje varijabli odstupanja $u$ odnosu na kineske i portugalske govornike, ali su jednako tako i govornici engleskog jezika naveli manje varijabli odstupanja u odnosu na govornike drugih jezika. Među govornicima romanskih jezika prisutne su razlike $\mathrm{u}$ samoprocjeni izgovora hrvatskoga kao J2 - najviše varijabli odstupanja navode govornici portugalskog, a podjednako govornici španjolskog i talijanskog jezika.

Općenito, svoj izgovor neizvorni govornici vrlo strogo procjenjuju (čak i oni na višim razinama poznavanja hrvatskog jezika). No, prosječna ocjena samoprocjene izgovora viša je na višim razinama poznavanja hrvatskog jezika jer je očekivano i izgovor objektivno bolji (slično za francuski piše Desnica-Žerjavić (2006)).

Najstrože su svoj izgovor procijenili govornici portugalskog jezika, potom kineskog, španjolskog, i njemačkog jezika, a najbolje govornici slavenskih jezika i engleskog jezika.

Bez obzira na J1 svi ispitanici smatraju da trebaju raditi na intonacijama u hrvatskom jeziku, a gotovo svi smatraju da trebaju raditi i na naglascima.

Veće ocjene vlastitog izgovora kod početnika prisutne su kod polaznika koji dulje uče hrvatski (iako je njihovo znanje jezika početničko) i kod onih čije je podrijetlo dijelom hrvatsko pa su imali priliku u obitelji slušati hrvatski (iako sami ne govore hrvatski). Oni koji imaju hrvatsko podrijetlo, ali nisu učili hrvatski jezik, niti su s roditeljima i rodbinom govorili hrvatski, svoj izgovor procjenjuju negativno.

Varijable koje predstavljaju problem govornicima mogu se dovesti u vezu s osobinama J1 - izgovor konsonanata u španjolskom u odnosu na hrvatski, mjesto naglaska u slavenskim jezicima u odnosu na slobodniju distribuciju naglasaka u hrvatskom itd.

Iz niskih ocjena samoprocjene zaključujemo da je važno tijekom učenja jezika korigirati i izgovor učenika kako bi govornici bili sigurniji u usmenoj komunikaciji na drugom jeziku.

Promišljanje o perceptivnoj analizi (objektivnom izgovoru govornika koji su sudjelovali u istraživanju) i niskim ocjenama kojima su ispitanici ocijenili vlastiti izgovor hrvatskog kao J2 navodi na zaključak da je izgovor objektivno ipak bolji od samoprocjene pa će sljedeća faza ovog istraživanja biti objektivna procjena koja će se potom usporediti s ovim rezultatima samoprocjene. 


\section{LITERATURA}

Banković-Mandić, I. (2012) Izgovorna obilježja učenika hrvatskoga kao drugoga i stranoga jezika na različitim stupnjevima znanja. Neobjavljena doktorska disertacija. Zagreb: Filozofski fakultet.

Banković-Mandić, I. i Čilaš Mikulić, M. (2016) Izlaganje "O bilježenju, izgovoru i prihvaćenosti hrvatskih standardnih naglasaka" na Istraživanjima govora - IX. znanstvenom skupu s međunarodnim sudjelovanjem. Zagreb, 8. - 10. prosinca 2016.

Banković-Mandić, I. (2016) Svjesnost inojezičnih govornika hrvatskog jezika o odstupanjima u izgovoru vokala. U Čolakova, Ž. (ur) Paisijeva čitanja - bugarska, lingvistika, slavistika (Паисиеви четения-бъдгаристична, лингвистика, славистика), 54, 1, dio A. Plovdiv: Paisii Hilendarski, University of Plovdiv, 368-379.

Banković-Mandić, I. (2018) Izgovor hrvatskog kao inog iz perspektive izvornih govornika. U Botica, S., Nikolić, D., Tomašić, J. i Vidović Bolt, I. (ur.) Zbornik radova šestoga hrvatskoga slavističkoga kongresa. Zagreb: Hrvatsko filološko društvo, 869-884.

Davis, L. M. (1970) Social dialectology in America: A critical survey. Journal of English Linguistics 4, $46-56$.

Desnica-Žerjavić, N. (2006) Strani akcent. Zagreb: FF press.

Granić, J. (1994) Standard u jeziku i standard u govoru. Govor 11 (2), 83-87.

Jakovčević, N. (1988) Jedno istraživanje stavova o jezičnim varijetetima. Govor 5 (1), 43-61.

Kalogjera, D. (2003) Prihvaćeni izgovor vs. received pronunciation. Govor 20 (1-2), 181-190.

Kišiček, G. (2012) Stavovi prema gradskim varijetetima hrvatskog jezika. Govor 29 (2), 149-167.

Mićanović, K. (2008) Hrvatski s naglaskom: standard i jezični varijeteti. Zagreb: Disput.

Mildner, V. (1999) Strani akcent u hrvatskom jeziku. U Badurina, L., Ivanetić, N., Pritchard, B. i Stolac, D. (ur.) Teorija i mogućnosti primjene pragmalingvistike. Zagreb - Rijeka: Hrvatsko društvo za primijenjenu lingvistiku, 529-532.

Mildner, V. (2009) Promjene u stavovima prema hrvatskim govornim varijetetima. U Požgaj Hadži, V., Balažic Bulc, T. i Gorjanc, V. (ur.). Med politiko in stvarnostjo: jezikovna situacija v novonastalih državah bivše Jugoslavije. Ljubljana: Univerza v Ljubljani, Filozofska fakulteta, 145-159.

Požgaj Hadži, V. (2013) Jezik između lingvistike i politike. Beograd: Biblioteka XX vek.

Sapir, E. (2013) Jezik: uvod u istraživanje govora. Zagreb: Institut za hrvatski jezik i jezikoslovlje.

Šafarić, I., Ćalušić, A. i Mildner, V. (2006) Procjena izgovora neizvornih govornika hrvatskoga jezika. Lahor 1, 49-60.

Škarić, I. (1999) Sociofonetski pristup standardnom naglašavanju. Govor 16 (2), 117-137.

Škarić, I. (2001) Razlikovna prozodija. Jezik 48 (1), 11-19.

Škarić, I. i Lazić, N. (2002) Vrijednosni sudovi o hrvatskim naglascima. Govor 19, 1, 5-34.

Škarić, I. i Varošanec-Škarić, G. (2003) Stupanj tolerancije hrvatskih govornika na "pogrešne“ naglaske. U Botica, S. (ur.) Zbornik Zagrebačke slavističke škole. Zagreb: Filozofski fakultet u Zagrebu, Zagrebačka slavistička škola, Hrvatski seminar za strane slaviste, 291-304.

Škiljan, D. (1987) Pogled u lingvistiku. Zagreb: Školska knjiga.

Varošanec-Škarić, G. i Kišiček, G. (2009) Izvanjske indeksikalne osobine govornika varaždinskoga i osječkoga govora. Suvremena lingvistika. 67 (1), 109-125. 


\section{SELF-EVALUATION OF PRONUNCIATION IN SPEAKERS OF CROATIAN AS L2}

Sociophonetic research shows that deviations in pronunciation in the public speaking of Croatian language are badly evaluated. In private communication there is greater tolerance to deviations. However, regional speech is not evaluated negatively in all languages.

The paper aims to show whether speakers of the Croatian language as L2 in selfevaluation could be grouped by their first language. The assumption is that the speakers of the related languages with the Croatian will notice fewer variables.

For this research 73 questionnaires were collected. Respondents speak the Croatian language on different CEFR language levels. The following variables were studied: intonations, vowels, consonants and accents. The questionnaire was open type so respondents could list some other variables. Also, respondents evaluated their pronunciation on a scale from 1 to 5 .

The results of this research could be a guideline for the Croatian language lecturer in pronunciation exercises.

Keywords: self-evaluation, pronunciation, Croatian as L2 